\title{
Developing the service value: a case study of waste management in offshore petroleum logistics
}

\author{
P. Engelseth \\ Department of Logistics, Molde University College, Norway
}

\begin{abstract}
This research concerns how waste can be perceived as a valued object from a supply chain prospective. The resource-based view of the firm supplemented by service-dominant logic in an overall frame of supply chain management is used to develop an analytic framework guiding this research. A single case study reveals how waste in petroleum logistics includes a role of waste as a traded product downstream in the supply chain. "Waste management" is discussed from a SCM perspective; an "afterlife" of the outbound product; a normal logistical flow. The flow from the supply base is reverse, but not the flow out of the supply base which also is associated with ownership and trading waste products. Waste management firms are specialised in creating logistics service through networking. In relation to petroleum logistics, waste management is a function associated with this overall logistics function in offshore petroleum production.

Keywords: petroleum logistics, waste management, resource-based view, supply chain management, networks.
\end{abstract}

\section{Introduction}

This case study focuses on the seemingly paradoxical topic of value associated with managing industrial waste in a petroleum logistics empirical setting. A number of scientific publications mention that there exists a value aspect to waste [1-12]. On the other hand, many publications also mainly focus on environmental impacts of waste management providing a view that waste management is needed mainly as a safeguarding mechanism to protect the 
environment [13-18]. In business practice a range of specialized firms incorporate waste management as a specialized business activity. These firms provide a service value associated with waste management as type of industry. This case study involves describing waste handling and management processes in an industrial network characterized by a high degree of outsourcing of waste management and operations. All firms that produce and thereby possess waste must to some degree manage and transact waste products. This case study aims to develop a supply chain management (SCM) based approach to developing customer-responsive waste flows; aligning waste management with SCM theory in general.

\section{Supply chain management}

SCM thinking is associated with systems dynamics theory [18]. System dynamics deals with aggregate rather than individual agents where individual action is unimportant [19]. This discerns SCM from logistics, which is more technical in nature. SCM involves studying complex networks of firms from a holistic perspective. From a normative viewpoint, SCM concerns, according to Lambert et al. [20] developing the level of integration. It concerns creating an understanding of how different supply chain actors work together to coordinate predominately logistical flows. Halldórsson et al. [21] describe SCM as a collection of conglomerate theories that are more or less well fit with each other including transaction cost analysis, the resource based view of the firm, principle-agent theory and network theory. "Logistics" implies production (transformation) associated in physical distribution, which waste is characterized as, with transport, inventory and goods handling. Logistics provides utility in the form of time, place and form features of goods upon delivery to a customer.

In line with Croom et al. [22], SCM can be described as different levels of analysis as "dyads", "chain" or "network". These conceptualisations are complementary. Dyads are business relationships, the immediate organizational context of interaction between two companies. Dyads are associated with relationship management and are by nature fundamentally reciprocally interdependent. In line with Emerson [23], the power-dependence in such relationships varies impacting on interaction processes. They encompass learning and innovation. Supply chains indicate a normative quest to integrate different firms following a linear flow of goods. SCM involves accordingly the integration of a functionally interlinked series of dyadic relationships characterised by sequential interdependencies. This is the core realm of SCM following the Lambert et al. [20] definition of SCM. The network, on the other hand, encompasses multiple-actor identity and pooling these identities; the potential to navigate trading with different business partners as well as the feature of interacting with multiple suppliers and multiple customers simultaneously. 


\section{The resource-based view supplemented by service-dominant logic}

The resource-based view (RBV) of the firm originated with the seminal works of Werenfeldt [24] and later developments by Barney [25]. Werenfeldt [24] put forward the view that most products require the services of several resources and most resources can be used in several products. This view is rooted in Penrose's [26] original view that services yielded by resources are a function of the way in which they are used - exactly the same resource when used for different purposes or in different ways and in combination with different types or amounts of other resources provides a different service or set of services. RBV is criticized due to oversight of the dynamism, environmental contingencies, and the role of the manager [27]. Barney [28], however, states in a more recent publication that the "...resource based theory suggests that purchasing and supply chain management will often have the attributes that can enable them to be sources of sustained competitive advantage". This indicates a strategic viewpoint of RBV pertinent to SCM; it encompasses supplier relationships. Core RBV thinking implies that firms are different from each other; this invites search for complementarity. Firms, are however different in character, and this is in part determined by their nature as bundles of resources, and in part by the nature of their context; organizational, social and natural environment. The RBV is here applied to study functionally-integrated supply chains.

Service-dominant logic (S-DL) is a marketing management approach associated with strategic understanding of customer value. This merging of the RBV and S-DL is also relatively uncomplicated since the fundamental writings in RBV, essentially Penrose's [26] "Theory of the Growth of the Firm", represent a vital foundation of S-DL thinking. S-D logic contributes to RBV by developing a value-oriented network interaction approach (Lusch and Vargo [29]). Value is also relational, and thereby the analytical framework becomes more inter-organisational. In line with Mintzberg [30], meaning is generated through network interaction and not through a single company's stand-alone strategic planning created in a boardroom. RBV is in this study developed using $\mathrm{S}-\mathrm{DL}$ to encompass interaction through dyads in networks. S-DL is more limited in encompassing, in line with empirical evidence brought forward by Håkansson and Persson [31], that each company must handle often a large set of dynamic business relationships. This brings us back to classification of SCM levels (Croom et al. [22]); all these SCM levels need to be encompassed as complementary theoretical components in developing the "SCM of waste management".

\section{Industrial waste and its value in supply chains}

Waste may, according to Smith [32], be defined in many ways. Is waste "resource"? The conception of "waste" is important because of strict government legislation associated with waste handling [33]. The European Council [1] defined that "Waste shall mean any substance or object in the categories, which 
the holder discards or is required to discard". Pongracz [8] stated that, one of the methods to define waste is by listing activities or substances that fall within the range of abovementioned defined categories. Pongracz and Pohjla [34] argued that the term waste as "a thing that its holder is to discard", meaning that the holders intend to throw this physical object away. Waste is created and perceived by supply chain actors first created then logistically handled. The notion of "discard" is a perception held by the waste creator. Waste, when leaving the waste producer may be disposed, reused, resold, or re-manufactured; this is conceptualised as "return flow"; waste is returned to a supply chain subject that originally produced the "waste".

According to De Brito and Dekker [15], waste management is the collection and processing of waste that has no longer any reuse potential. The management of waste is associated with a "waste hierarchy": 1) prevention, 2) re-use, 3) recycling, 4) recovery and 5) disposal [35]. The waste solutions involve different logistics and perceptions of value. From the perspective of waste producers, waste management involves specialized resources distinct from the main production of a firm. This implies also using specialized equipment and competence in handling waste. Waste management firms are accordingly bundles of resources specialized at managing and handling waste. The strategic importance of waste management companies in a network setting constitutes its identity, and this identity generates perceptions of complementarity stimulating networking including trading. In a supply chain dyad, both firms are in some manner attracted to each other, envisioning reaping benefits of perceived complementarities. Based on this perception the relationship evolves seeking a solution to the waste problem of the waste producer provided by the waste management firm. As Foss [36] states "...capabilities belonging to networks of firms clearly emerge from the interplay of firm capabilities; not the other way around." Furthermore, Hayek [37] states, it is through interaction relationships that solutions to practical problems are found since knowledge is never limited to a single mind. This implies, following Richardson [38] a view that waste management cannot be viewed in isolation from the perspective of single firm. The drawing of inter-firm boundaries and sourcing within or outside of a firm's waste operations including its logistics are accordingly an important issue in waste management. As the degree of specialization and outsourcing increases form a supply network perspective, waste management emerges as embedded in a chain of strategically managed sequentially interdependent dyadic relationships. This entails a need for SCM; to integrate the supply chain's logistics and other operations resources to improve the coordination of these activities. Waste management in a supply network context involves sourcing decisions; the exit or invite of new chain actors. As more waste management operations are outsourced, the importance of purchasing as well as networking through business relationships increases in importance [39].

Since waste is envisioned as part of a returns flow in a supply chain, in logistics, waste management is often considered a form of reverse logistics. Rogers and Tibben-Lembke [11] define reverse logistics as: "The process of planning, implementing, and controlling the efficient, cost effective flow of raw 
materials, in-process inventory, finished goods and related information from the point of consumption to the point of origin for the purpose of recapturing value or proper disposal". From this reverse logistics definition it can be argued that the purpose of reverse logistics is to recapture value and, second, disposal if the return materials do not carry any value. De Brito and Dekker [15] claim that "reverse logistics" differs from "waste management" because the last part of reverse logistics definition by Rogers and Tibben-Lembke [11] mainly concerns the efficient and effective collection and processing of waste, that is, products for which there is no longer any reuse potential. De Brito and Dekker [15] support their argument that waste is something which has limited re-use possibilities. However, Shakantu et al. [40] argue that there are similarities between some of the processes used by product recovery networks and waste disposal networks. Cherrett et al. [41] claim that the similarities between reverse logistics and waste management is most evident from a supply side perspective where used products are collected from many sources and need to be consolidated for further processing and transportation. However, Fleischmann et al. [42] argue that a flow of recovered products is directed towards a reuse market and waste streams eventually end at landfill sites or incineration plants after various treatment processes. This indicates that the destination of a waste flow in a predefined systems-configured supply network structure does not always entail, literally speaking, a reverse back-to-origin flow. De Brito and Dekker [15] argue that depending on the type of reverse process, products may not necessarily be returned to their point of origin, but to a different point for recovery. Cherrett et al. [41] argue, that the delivery of return materials back to disposal sites and treatment centres is a natural extension of reverse logistics. Hillegersberg et al. [43] and Cherrett et al. [41] characterize transportation is one of the main attributes of reverse logistics. This discussion evokes some confusion regarding what actually constitutes "waste" as well as its place as management practices in in a supply chain context. Is waste only what always has been and always will be waste? Or may waste be transformed into something desirable, a product? Is waste management a function or classification of type of firm?

The upstream offshore petroleum logistics operations secure platform operations through managing supplies of goods and services through on land supply bases, modelled as logistics flows in figure 1 .

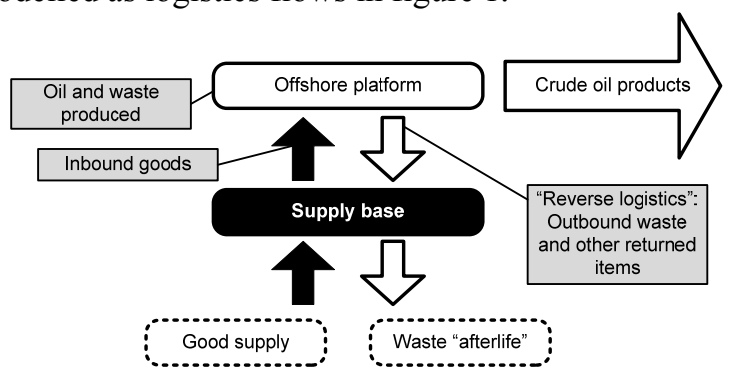

Figure 1: Petroleum logistics and waste management. 
Petroleum logistics encompasses all logistics flows. Crude oil is transported directly from the platform to refineries on land, and not through the supply base. Figure 1 indicates how, "reverse logistics" may be deemed conceptually superfluous, especially since logistics associated with the "afterlife" of waste hardly can be characterised as "reverse". The concept of "value-in-use" is central to S-DL and implies that "value" human perception from the perspective of the service recipient, the customer. Following S-D logic, value is not information (objective); it is perception (subjective), a form of sense making that takes place in a network of actors [29]. Value is impacted by interaction in business relationships. Since value is associated with integration and communication, the type of value created and obtained by a specific collaboration is accordingly dependent on the degree of maturity of that collaboration [44]. The combined competencies of the parties in the supply chain affect and shape the value proposition of collaborative supply networks. Mollenkopf and Closs [10] provide through a study examples of how improved reverse logistics flows including handling waste items creates increased value at different stages of a flow of goods. Waste, as "product", is a transformable resource. While for the waste producers waste is an annoyance, a waste management company perceives waste as a raison d'être, a resource with product-type features. A notion of waste as resource emerges when taking a supply chain perspective.

\section{Method}

This was an explorative quest. A single case was studied providing detail rather than comparison. Informants came from four different companies: the supply base Vestbase, a waste management company handling waste operations called Norsk Gjenvinning, a waste management company trading waste called Maritime Waste Management, and Norske Shell, an oil as well as a waste producer. Semi-structured enabled an emergent design, interviews carried out during a period of four months. Questions were organized as follows: 1) waste as technical resource, 2) waste management practices and perceptions, 3) the logistics of waste in potentially a "reverse" flow, and 4) conceptions of value. Each interview carried an average of 10 main questions. Each main question was further extended to several sub questions. A single interview lasted long an average of 1 hour. Limitations are associated with the single case study format which allows deeper insight, but also limits generalization [45]. This form of case study permits theory building [46] and thereby theoretical generalizability [47]. It may therefore contribute by generating theoretically founded ideas to discourse both in academia as well as in business practice; a foundation for waste management innovation based on new insight.

\section{Case description}

The Vestbase supply base is located in Kristiansund Norway. It functions as an industrial park with harbour and terminal facilities. There are currently more than 
60 firms located with rented facilities on this base. All these firms are involved in either producing or handling at least miniscule amounts of waste. The studied waste flow involves Norske Shell as waste producer at its offshore Heidrun platform. Shell has strategically chosen to outsource its waste management procedures and operations. Mainly it is the supply base that manages waste received from offshore installations and coordinates their activities with the specialized waste management firm, Norsk Gjenvinning. Another specialized waste management firm, Maritime Waste Management handles trading waste, facilitating the continuing downstream flow of waste from Vestbase. This firm is a subsidiary of Vestbase. In addition, transport firms, mainly both road and shipping play an important role in waste management. These are the four main companies considered in this case; 1) Vestbase, 2) Norske Shell, 3) Norsk Gjenvinning and 4) Maritime Waste Management. These companies are first considered in brief.

Vestbase was established based on an investigation in the early 1970 s by an oil committee appointed by the Norwegian government to place Kristiansund on the map relevant for the oil business. Vestbase is $100 \%$ owned by NorSea Group AS. NorSea Group is the leading supplier of integrated logistics system and base services to the Norwegian oil and gas industry. Vestbase facilitates several production platforms, drilling rigs and subsea installations outside Krisitiansund. Large amounts of waste are produced from oil platforms. This waste is shipped to Vestbase for treatment and further processing by other companies at other locations; Vestbase carries out the logistics of receiving, and dispatching this waste.

Norsk Gjenvinning (NG) is Norway's leading environmental service provider. Maritime Waste Management (MWM), closely associated with Vestbase, offers waste management services at all bases in Norway. It controls and co-ordinates waste flows through Vestbase. At Vestbase MWM works along with Norsk Gjenvinning to handle, manage and transport of offshore waste generated by oil companies. NG mainly carries out waste operations, while WMS manages the flow of waste into and from Vestbase.

NG handles four types of waste: 1) industrial waste, 2) bulk waste, 3) metal waste, and 4) hazardous waste. All waste is transported from the platform on platform supply vessels (PSV) designed to handle a range of different cargo in tough weather conditions. The Vestbase personnel first receive and handle waste from these ships before turning them over to NG who then handles this waste. After processing by NG, waste is sent to the downstream recipients brokered by MWM. Waste implies costs for Norske Shell while for MWM and Norsk Gjenvinning, waste represents a source of revenue.

\section{Analysis}

The described the petroleum logistics goods flow reveals a logistical loopformed flow that functions to support petroleum raw material production at the offshore platform. It is fair to say that the studied flows, both outbound goods and return flows, are services supporting the main petroleum production 
offshore. These supporting activities are substantial in importance and this is a reason to characterise this support flow as part of the main production. In any case, waste management is a vital supporting function; logistical and embedded in a network context demanding coordination following SCM principles. The first logistical part of the described waste flow is clearly reverse. While upstream, closer to the platform, waste is seemingly worthless and value emerges downstream as recipients of waste are found in the network. Two aspects of waste are indicated; 1) as service by specialist forms supporting the flow of waste, and 2) a gradually emergent value in waste itself as it is transformed into a tradeable item downstream in the supply chain. Waste ownership is an important issue. This evokes disparity of value perceptions also opens up for the view that transacting waste demands specialized competence not only in handling waste, but also in transacting it. WMS is expression of a company reaping rents based on complementarities educed through inter-firm interaction. This need for specialized competence opens up for understanding the grounds for outsourcing waste management since it involves both need for specialized waste handling resources and specialized knowledge resources to manage the waste including marketing it. Following S-D logic, waste management as supply chain function develops customer-supplier interaction to secure customer value objectives. SCM practices may support this vital dyadic interaction embedded in relatively integrated chains managing waste to and through Vestbase.

The flow of waste is a form of logistics involving transport, storage, terminal activities and handling. However, as the case also shows, as waste is transformed into a traded item two aspects of service provision merge in the described network. First specialized waste management firms provide service to waste producers aiming to move waste from the platform in accordance with government legislation governing oil production. Furthermore, waste, when processed also indicates that "manufacturing" as concept is pertinent to waste management. Managing waste at core implies a form of production; while the primary functionality of production in petroleum logistics associated with supplying petroleum products to customers. Waste production is a negativelyladen off-spin of this primary production. As a gradually tradable item, waste is rendered into goods. Maybe it should be considered as goods all along even though its flow starts as an item of discard? Waste as "goods" implies waste is valued; considering it as a resource object, a tradable product, in supply chains subject to the logistics of time, place and form transformation. This logistics is fundamentally the same as inbound logistics to the platform. The same as the goods, waste is also traded. Waste may be classified accordingly as not only goods, but products. As products the marketing aspect of waste is evoked.

Customer-supplier interaction takes accordingly two forms of exchange in the case. First is the interaction between NG and mainly their waste producing customer Norske Shell. However, NG must also simultaneously collaborate through other business relationships, such as Vestbase, shipping companies, logistics service operators and more. This implies collaboration through established structurally dynamic supply chains. Value in this scenario is rooted in the perceived network identity of the two core waste management companies, 
NG and MWM, very similar to identities of any logistics service provider (LSP) who never claims title to a product. Waste management companies may be classified accordingly as a specialised type of LSP. Value is associated with two prime aspects: 1) transforming waste as well as 2) network trading.

\section{Conclusion}

Waste management is proposed, grounded on this petroleum logistics specific context, rather than as a form of reverse logistics be considered a form of industry that is represented by unique supply chains. Waste management is logistically an afterlife version of supply chains with close resemblance of other forms of supply chains, but clearly distinct from the preceding stages of product supply. The logistics of waste management is proposed considered an empirical variation of supply chain management perspective. Waste management, as any other form of activity in a supply chain, is associated with service provision and customer value. Waste management as service provision is proposed classified as a type of LSP. "Waste management" when used to characterise firms in a network provides sourcing-related identity. Creating service value is dependent on interaction through business relations as in any other business. The waste management industry involves, however, particularities that include, potentially in part as when waste is shipped from platform to supply base, a reverse flows of "goods". Knowing waste as "resource" (as goods) creates foundation for clearer SCM initiatives.

Research in developing the supply of waste concerns simply goods or products. Waste has particular characteristics, just as bananas or ships. Furthermore, given the high degree of outsourcing, waste management as service, more precisely as LSPs, represent a body of literature beneficial to developing waste management. Finally, the predominant classifying of waste management as something logistically "reverse" is deemed empirical, not conceptual. Further studies aiming to refining this understanding of the logistics and supply chain management in waste management are called for. This includes manly considering waste as 1) an empirical phenomenon in SCM and logistics, as well as considering 2) waste management as logistics service provision, a way to classify firms in the network, including considerations of outsourcing.

\section{References}

[1] European Council, Council Directive 91/156/EEC of 18 March 1991 amending Directive 75/442/EEC on Waste, Official Journal, L 078, 26/03/1991, pp. 32-37, 1991.

[2] Gourlay, K. A., World of Waste: Dilemmas of industrial development, London: Zed Books, 1992.

[3] Kirkpatrick, N., Selecting a waste management option using a Life Cycle Analysis Approach, in: Life Cycle Analysis, No. 3, Surrey UK: Pira International, 1992. 
[4] Woodruff, R. B., Schumann, D. W., and Gardial, S. F., Understanding value and customer satisfaction from the customer's point of view, University of Tennessee Survey of Business, 28(1), pp. 33-40, 1993.

[5] Lox, F., Waste Management - Life Cycle Analysis of Packaging, Final Report. Study Realized by the Consortium Vrije Universiteit Brussel, Vlaamse Instelling voor Technologisch Onderzoek, Belgian Packaging Institute, for the European Commission, DG XI/A/4. 1994.

[6] Cheyne, I. and Purdue, M., Fitting definition to purpose: The search for a satisfactory definition of waste, Journal of Environmental Law, 7(2), pp. 149-168, 1995.

[7] Rutner, M. S., and Langley, Jr. J. C., Logistics Value: Definition, and Measurement, The International Journal of Logistics Management, 11(2), pp. 73-82, 2000.

[8] Pongracz, E., Re-defining the concept of Waste and Waste Management. Evolving the Theory of Waste Management, (Doctoral dissertation), Oulun Yliopisto, Finland, 2002.

[9] Pongracz, E., and Pohjla, V. J., Redefining waste, the concept of ownership and the role waste management, Resources, Conservation and Recycling, 40(2), pp. 141-153, 2004.

[10] Mollenkopf, D. A. and Closs, D. J., The Hidden Value in Reverse Logistics, Supply Chain Management Review, 9(5), pp. 34-43, 2005.

[11] Rogers, D. S., and Tibben-Lembke, R., Going Backwards: Reverse Logistics trends and Practices, Reverse Logistics Executive Council, 1999.

[12] Muir, W., "Creating Value in Our Everyday Waste", Published in Treehugger, http://www.treehugger.com/corporate-responsibility/creatingvalue-in-our-everyday-waste.html

[13] McKinney, J. B., Concepts and definitions, in: McKinney, J. B., \& Johnstone, M. (Eds) Fraud, Waste and Abuse in Government: Causes, Consequences and Cures, Philadelphia Institute for the Study of Human issues, pp. 1-7, 1986.

[14] Stock, J., Speh, T. and Shear, H., "Many Happy (Product) Returns", Harvard Business Review, Vol. 80 No. 7, pp. 16-187, 2002.

[15] De Brito, M. P. and Dekker, R., A Framework for Reverse Logistics, Erasmus Research, Institute of Management Report Series Research in Management, Rotterdam: Erasmus University, 2003.

[16] Moutavtchi, V., Stenis, J. and Hogland, W., Solid waste management by application of the WAMED model, Journal of Material Cycles and Waste Management, 12(2), pp. 169-183, 2010.

[17] Mohareb, E.A., MacLean, H.L. and Kennedy, C.A., Greenhouse Gas Emissions from Waste Management. Assessment of Quantification Methods, Journal of Air \& Waste Management Association, 61(5), pp. 480-493, 2011.

[18] Forrester, J.W., Industrial Dynamics: A Major Breakthrough for Decision Makers, Harvard Business Review, 36(4), pp. 37-66, 1958. 
[19] Gilbert, N. Agent-based models, London UK: Sage Publications Inc., p. 20, 2007.

[20] Lambert, D.M., Cooper, M.C. and Pagh, J.D., Supply Chain Management: Implementation Issues and Research Opportunities, The International Journal of Logistics Management, 9(2), pp. 1-19, 1998.

[21] Halldórsson, A., Hsuan, J. and Kotzab, H. Complementary theories to supply chain management revisited - from borrowing theories to theorizing, Supply Chain Management: An International Journal, 20(6), pp. 574-586, 2015.

[22] Croom, S., Romano, P. and Giannakis, M., Supply chain management: an analytical framework for critical literature review, European Journal of Purchasing and Supply Management, 6(1), pp. 67-83, 2000.

[23] Emerson, R.M., Power-Dependence Relations, American Sociological Review, 27(1), pp. 31-41, 1962.

[24] Werenfeldt, B., A resource-based view of the firm, Strategic Management Journal, 5(2), pp. 171-180, 1984.

[25] Barney, J. B., Firm resources and sustained competitive advantage, Journal of Management, 17(1), pp. 99-120, 1991.

[26] Penrose, E., The Theory of the Growth of the Firm, Oxford: Oxford University Press, 1959.

[27] Simon, D. G., Hitt, M. A. and Ireland, R. D., Managing firm resources in dynamic environments to create value: Looking inside the black box, Academy of Management Review, 32(1), pp. 273-292, 2007.

[28] Barney, J. B., Purchasing, supply chain management and sustained competitive advantage: The relevance of resource-based theory, Journal of Supply Chain Management, 48(2), pp. 3-6, op cit. p. 3, 2012.

[29] Lusch, R.F. and Vargo, S.L., Service-Dominant Logic. Premises, perspectives, possibilities. Cambridge UK, Cambridge University Press, pp. 159-160, 2014.

[30] Mintzberg, H., The Rise and Fall of Strategic Planning, Edinburgh Gate UK, Prentice Hall, 1994.

[31] Håkansson, H. and Persson, G., Supply Chain Management: The Logic of Supply Chains and Networks, The International Journal of Logistics Management, 15(1), pp. 11-26, 2004.

[32] Smith, J. T., The challenges of environmentally sound and efficient regulation of waste the need for enhanced international understanding. Journal of Environmental Law, 5(1), pp. 91-107, 1993.

[33] Fleischmann, M., Reverse Logistics Network Structures and design, ERIM Report, ERS-2001-52-LIS, Rotterdam: Erasmus University, 2001.

[34] Pongracz, E., and Pohjla, V. J., Redefining waste, the concept of ownership and the role waste management, Resources, Conservation and Recycling, 40(2), pp. 141-153., op cit. p. 68, 2004.

[35] European Council., Council directive 2008/98/EC on waste. Waste Framework Directive, op cit. p. 1, 2008.

[36] Foss, N. J., Networks, capabilities, and competitive advantage, Scandinavian Journal of Management, 15, pp. 1-15., op cit. p. 3, 1999. 
[37] Hayek, F. A. The Use of Knowledge in Society, American Economic Association, 35(4), pp. 519-530, 1945.

[38] Richardson, G. B., The Organization of Industry, The Economic Journal, September, pp. 883-896, 1972.

[39] Gadde, L.-E., Håkansson, H. and Persson, J., Supply Network Strategies, Chippenham UK: Wiley, 2010.

[40] Shakantu, W., Tookey, J. E. and Bowen, P. A., Defining the role of reverse logistics in attaining sustainable integration of materials delivery with construction and demolition waste management, in Proceedings of the CIB W107 International Conference on Creating a Sustainable Construction Industry in Developing Countries, Cape Town, pp. 97-103, 2002.

[41] Cherrett, T., Maynard, S., McLeod, F. and Hickford, A., Reverse logistics for the management of waste, in Green logistics: improving the environmental sustainability of logistics, London: Kogan Page, pp. 242262, 2010.

[42] Fleischmann, M., Krikke, H. R., Dekker, R. and Flapper, S. D. P., A characterization of logistics networks for product recovery, Omega, International Journal of Management Science, 28(6), pp. 653-666, 2000.

[43] Hillegersberg, J van., Zuidwijk, R., Nunen, J van. and Eijk, D. van., Supporting return flows in the supply chain, Communications of the $A C M$, 44(6), pp. 74-79, 2001.

[44] Bititci, U. S., Martinez, V., Albores, P. and Parung, J., Creating and Managing Value in Collaborative Networks, International Journal of Physical Distribution and Logistics Management, 34(3-4), pp. 251-268, 2004.

[45] Voss, C., Tsikriktsis, N. and Frohlich, M., Case research in operations management, International Journal of Operations and Production Management, 22(2), pp. 195-219, 2002.

[46] Eisenhardt, K. M., Building theories from case study research, Academy of Management Review, 14(4), pp. 532-550, 1989.

[47] Meredith, J., Building operations management theory through case and field research, Journal of Operations Management, 16(4), pp. 441-454, 1998. 